practices that avoid the label of piracy and its legal consequences, which has helped them to become accepted in parts of the commercial and technological establishment.

Today's intellectual-property system is built on decisions made in the past. In revealing how piracy affected those decisions, Johns's history provides a valuable addition to the literature. However, the book does not deal with the future implications of piracy. Lacking a practical understanding of current intellectualproperty law and practice, Johns is unable to draw lessons or make predictions or recommendations.

Piracy is an aspect of intellectual-property dynamics that scientists, lawyers, policymakers, business people and consumers should understand. When pirates gain the upper hand, innovators suffer and quality declines. But when exclusivity becomes too strong, society loses the benefits of access. A constant effort is required to balance the interests of innovators and copiers, and to nurture a healthy creative environment. Michael Gollin is a law partner at Venable LLP in Washington DC and author of Driving Innovation. $\mathrm{He}$ chairs the group Public Interest Intellectual Property Advisors, whose forthcoming book is Intellectual Property and Human Development. e-mail:magollin@venable.com

of the central dogma - that information flows in one direction, from DNA to RNA to proteins - also dates from this period, along with the gradual realization that the structures and functions of molecules in cells are more complicated than he had earlier assumed.

Olby brilliantly follows Crick through these creative years. By highlighting the scientist's interactions with a growing group of others devoted to developing the field, he captures the excitement, false dawns and triumphs that followed the Watson-Crick model of DNA. Olby is fair to all of the early participants in DNA work: Linus Pauling, Maurice Wilkins and, above all, Rosalind Franklin and her collaborators at King's College London. Watson and Crick used Franklin's data, and benefited from a breakdown in relations between Franklin and Wilkins that interrupted Wilkins's work on the molecule. The full story emerged only after the Nobel prize was awarded in 1962 to Watson,

\section{Francis Crick: Hunter of Life's Secrets by Robert Olby \\ Cold Spring Harbor Laboratory Press: 2009 450 pp. \$45, £30}

Francis Crick was not your run-of-the-mill scientist, as Robert Olby makes clear in his superb biography. A tall man given to verbal diarrhoea and infectious laughter, Crick did his Nobel-prizewinning work before he finished his $\mathrm{PhD}$. His thesis, on the $\mathrm{X}$-ray analysis of protein structure, provided him with skills to appreciate the molecular arrangement of DNA, but his work with James Watson was done in his spare time. Crick included an offprint of their 25 April 1953 Nature paper, the most fundamental in twentieth-century life sciences, in the back of his thesis as proof that he was a published researcher.

The Cambridge thesis was his second attempt at a doctorate. His first, in physics at University College London, was interrupted by the outbreak of the Second World War, during

which he worked on mine research for the Admiralty. After the war, Crick convinced the Medical Research Council (MRC) to give him a studentship to apply physics to biology. He went to Cambridge, first to the Strangeways Research Laboratory, and then to what is now known as the MRC Laboratory of Molecular Biology (LMB).

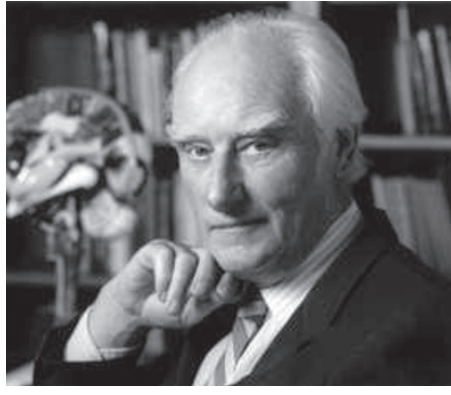

Francis Crick: no ordinary scientist. Crick and Wilkins; by then, Franklin had died, tragically young, of ovarian cancer. In 1952, both Franklin and Pauling were close to coming up with the structure themselves.

Issues of priority generate passion, but Olby's account can be recommended for its dispassionate analysis and mastery of archival sources. Crick's long-time collabo-

Discovering the structure of DNA saved his career. Lawrence Bragg, director of the Cavendish Laboratories where the LMB was then housed, had grown tired of Crick's boisterous behaviour. After the DNA paper, Bragg held a different view and Crick stayed at the LMB until 1976. His contributions to the development of molecular biology and genetics, and to our understanding of the genetic code and of transfer RNA, ribosomes and messenger RNA, are without parallel. His formulation ration with Sydney Brenner, another scientific giant, is given its due. So, too, are Crick's later decades spent at the Salk Institute in La Jolla, California, where he became a neuroscientist. Crick led a privileged existence there, able to invite scientists whose work he admired to spend months with him.

Brash young physicist turned molecular biologist; successful molecular biologist turned neuroscientist: there is symmetry to Crick's discipline changes, but hubris as well. For Crick

\title{
Stamps celebrate Royal Society scientists
}

To mark the Royal Society's 350th anniversary, the UK Royal Mail has issued a set of postage stamps featuring ten prominent fellows, each representing a 35-year period. Five are shown below (left to right): Alfred Russel Wallace, Joseph Lister, Ernest Rutherford, Dorothy Hodgkin and Nicholas Shackleton.

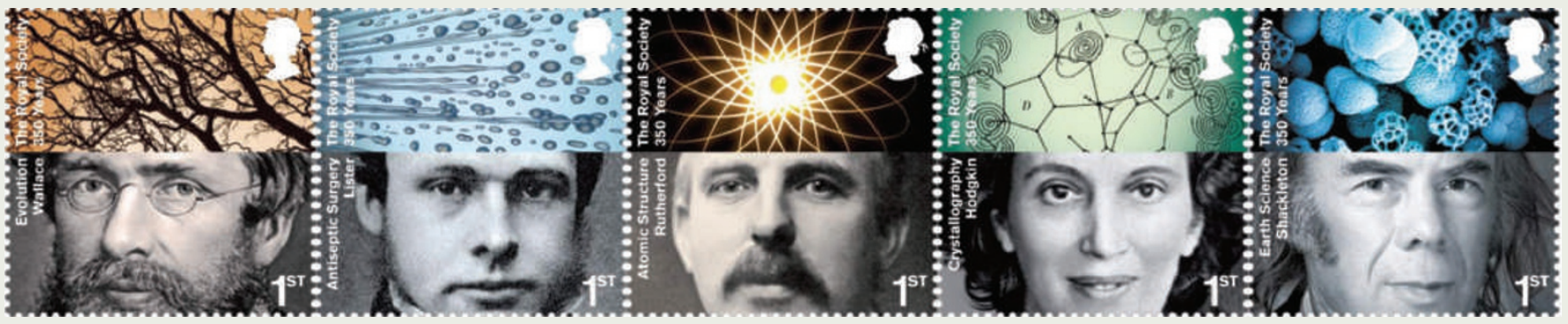


wanted to solve the ultimate problem, that of the physical basis of consciousness. The man who, in 1953, supposedly announced to drinkers in The Eagle pub in Cambridge that he had discovered the secret of life, was working in 2004, on his deathbed, on a paper proposing that the claustrum might be the key brain structure in producing consciousness. Olby works hard to put a positive spin on Crick's influence on consciousness research, in terms of support and the number of workers in the field. He stops short of suggesting that Crick was yet another great scientist who did not know when to retire and let younger people take over. Nevertheless, that conclusion could be drawn.

W. F. Bynum is emeritus professor of the history of medicine at University College London and author of The History of Medicine: A Very Short Introduction.

e-mail:w.bynum@ucl.ac.uk

\section{How lateral thinking saved lives}

\section{Martin Kemp is struck by the surreal quality of a home-made iron lung.}

There is no more-telling formula associated with surrealism than the words of the nineteenth-century French poet Comte de Lautréamont, who aspired to create something "as beautiful as the chance encounter of a sewing machine and an umbrella on an operating table".

Currently on show at the Mori Art Museum in Tokyo is the perfect surrealist object. A giant pair of bellows, of exactly the type used to resuscitate a domestic fire, is operated by a rude wooden lever that is pivoted on an arch of jointed pipes. It is tethered to a coffin-like wooden box, which is in turn anchored to a rickety iron bed. Patches on the leather lung of the bellows testify to its sustained use. On the wooden lid a series of stained rings speak of its occasional use as a table for hot beverages. It is a truly extraordinary object. To understand what it is really is - or was - we must return to the seventeenth century.

John Mayow, a physician at All Souls College at the University of Oxford, UK, was a member of the illustrious circle that included Christopher Wren, Robert Hooke and Thomas Willis, founder members of the Royal Society. Mayow's 1688 treatise On Respiration established the first mechanical basis for how humans breathe.

Mayow wrote that "if a bladder with most of the air pressed out of it, and tied by a tight ligature around the sphincter, be placed in a glass from which the air is afterwards exhausted, we shall at once see the bladder swell and become greatly distended," adding that it is "a rather pretty sight". The plate accompanying the treatise shows a pair of bellows to support his argument. Mayow, who also showed that the life-giving properties of air could be removed by combustion, died in 1679 aged 36, and is less well-known than he should be.

Given his early discovery of what came to be ponderously called external negative pressure ventilation, it is perhaps surprising that it was not until 1927 that a machine using this principle was invented to aid those whose respiratory systems were failing. The invention, which became known as the iron lung, is credited to the Harvard University physician Louis Agassiz Shaw and his colleague, the pioneer of industrial medicine, Philip Drinker. They had been sponsored in their research by the Consolidated Gas Company of New York. Their device consisted of an iron cabinet from which air could be evacuated by two vacuum-cleaner power units. It made a spectacularly successful debut on 12 October 1928 at Boston Children's Hospital in Massachusetts, where it resuscitated a child who had faced what seemed an inevitable death.

The iron lung, in its sleeker version as a polished or enamelled metal cylinder punctuated by windows and equipped with an angled mirror that allowed patients to see their surroundings, came into its own during the polio outbreaks of the 1940s and 1950s. The respirators enabled those whose chest muscles had been paralysed by the disease to breathe, and stood in diagonally serried rows in large wards while solicitous nurses filed by.

Anyone acquainted with such high-tech versions would barely recognize the wooden cabinet with bellows as an iron lung. Indeed, iron is not the most evident material used in the device. But it is indeed a respirator, and one that performed sterling service for a dozen or more years at the Lansdowne Hospital in Cardiff, UK, before being retired in the late 1950s. It seems that the bellows lung was put together by resourceful hospital engineers, presumably to save money. Only immediately available materials were used, such as wood, leather and tacks, and a hospital bed was commandeered. The whole ensemble declares the potency of artisanal resourcefulness.

The utilitarianism of the bellows lung chimes with surrealism in two respects. The first is that the leaps of lateral imagination that lay behind the incongruous juxtaposition of objects in surrealism find a clear parallel in the Welsh engineers' brilliant insight that a giant pair of traditional bellows could be combined with a wooden box and bed to do the same job as the manufactured item. The second is that how we look at an object varies over time and in settings other than those for which it was conceived. Now that the bellows lung features in historical displays, we cannot help but see it as a strange and wondrous thing alongside the other technological dinosaurs that fascinate us in museums of science.

Martin Kemp is emeritus professor in history of art at the University of Oxford, Oxford, UK.
This makeshift respirator was used in a UK hospital until the late 1950s.
The iron lung is on display at the Mori Art Museum in Tokyo until 28 February, and is part of the Science Museum's permanent collection in London. 